\title{
The effect of oropharyngeal aspiration before position change on reducing the incidence of ventilator- associated pneumonia
}

\author{
Ayşe Akbiyik $^{1}$ - Ziynet Hepçivici ${ }^{2}$ - Ismet Eşer ${ }^{3} \cdot$ Mehmet Uyar $^{4} \cdot$ Perihan Çetin $^{5}$
}

Received: 4 October 2019 / Accepted: 4 December 2019 / Published online: 24 November 2020

(C) Springer-Verlag GmbH Germany, part of Springer Nature 2019

\begin{abstract}
The aim of this study was to investigate the effect of oropharyngeal aspiration on ventilator-associated pneumonia (VAP) incidence just prior to changing patient position. This randomized controlled experimental study was conducted between July 2015 and April 2019 in anesthesiology and reanimation of intensive care unit (ICU). The patients of experimental group underwent oropharyngeal aspiration under surgical aseptic conditions before each position change. Patients of the control group received oropharyngeal aspiration only as needed. The mean age of the patients was $62.87 \pm 17.33$ years. The mean and median duration of stay in the ICU were $27.28 \pm 30.69$ and 18.00 days respectively. The mean and median of duration of the mechanical ventilation support were $26.72 \pm 30.65$ and $18.00(\min 4$; $\max 168)$ days respectively. Thirty percent of the patients were VAP. The mean duration of VAP development was $7.50 \pm 5.07$ days. The rate of VAP development was 11.23/1000 mechanical ventilator days. Only $8.3 \%$ of the experimental group patients developed VAP; $91.7 \%$ of the control group patients developed VAP. The VAP rate in the control group was 16.82/1000 mechanical ventilator days and the VAP rate in the experimental group was 2.41/1000 mechanical ventilator days. Most VAP agents were multidrug resistant. Distribution of isolated microorganisms was as Acinetobacter baumannii, Pseudomonas aeruginosa, Corynebacterium striatum, Staphylococcus aureus, Providencia stuartii, Serratia marcescens, Stenotrophomonas maltophilia, and Aspergillus flavus. In our study, it was concluded that oropharyngeal aspiration performed prior to patient position change prevented the development of VAP.
\end{abstract}

Keywords Mechanical ventilation $\cdot$ Mechanical ventilator $\cdot$ Pneumonia $\cdot$ Oropharyngeal aspiration $\cdot$ Change of position

\section{Introduction}

VAP is one of the health care-associated infections (HCAIs) that is common in critically ill patients, prolongs hospital stay, and significantly increases mortality and additional health care costs $[1,2]$. VAP is defined as pneumonia that develops after the first $48 \mathrm{~h}$ of mechanical ventilation support. VAP remains a major problem in ICUs where mechanical ventilator support

Ayșe Akbiyik

ayseakbyk@hotmail.com; ayse.akbiyik@ikc.edu.tr

Ziynet Hepçivici

ziynetert@yahoo.com

Ismet Eșer

iseser54@yahoo.com

Mehmet Uyar

uyar.mehmet@gmail.com

Perihan Çetin

pcetin71@gmail.com is widely used [3]. The incidence of VAP by the International Nosocomial Infection Control Consortium (INICC) was 13.6/ 1000 ventilator days, although the mortality rate of VAP was higher in critically ill patients, it was reported to be in the 24 to $76 \%$ range [4].

Bacterial colonization of the upper airways and gastrointestinal tract and aspiration of contaminated secretions into the lower airways play a role in the pathogenesis of VAP. The

1 Faculty of Health Sciences, Izmir Katip Celebi University, Izmir, Turkey

2 Faculty of Medicine, Anesthesiology and Reanimation Intensive Care Unit, Ege University, Bornova, Turkey

3 Faculty of Nursing, Department of Fundamentals of Nursing, Ege University, Bornova, Turkey

4 Faculty of Medicine, Department of Anesthesiology and Reanimation, Ege University, Bornova, Turkey

5 Vocational School of Health Services, Izmir Katip Celebi University, Izmir, Turkey 
microorganisms caused the pneumoniae to reach the lower respiratory tract by aspiration of oropharyngeal secretions, inhalation of contaminated aerosols, hematogenous spread (rare), and bacterial translocation from the gastrointestinal tract $[4,5]$.

Streptococcus pneumoniae, Haemophilus influenzae, Staphylococcus aureus (methicillin-sensitive), enteric gramnegative rods, and Moraxella catarrhalis are the most common agents in the VAP (early period) which occurs during the first 4 days of mechanical ventilation therapy. In VAP (late period) occurring on the fifth and subsequent days of mechanical ventilation treatment, the most common agents are Pseudomonas aeruginosa, Acinetobacter spp., Enterobacter spp., or $S$. aureus (methicillin resistant) [6-9].

There are widely used pharmacological and nonpharmacological applications for VAP prevention. The measures involved in these interventions are the use of stress ulcer prophylaxis, oral care with chlorhexidine, hand washing, use of protective clothing and gloves, patient position (half-sitting position), avoiding excessive stomach volume and early enteral nutrition, oral intubation, changing ventilator circuits at appropriate time intervals, temperature and humidity modifiers, chest physiotherapy, non-invasive mechanical ventilation, and oropharyngeal and endotracheal aspiration in case of indication [1, 4, 10-12].

Microaspiration of oropharyngeal secretions, the primary pathway in the formation of VAP, has led researchers to focus on the detection of applications to prevent microbial colonization. Some of these applications are continuous or intermittent oropharyngeal aspiration, closed system aspiration versus open system aspiration, extensive oral care, and oropharyngeal aspiration as needed $[1,4,10,13-15]$. When the patient is turned to position, the outbreak accumulated in the oral cavity is more likely to move to the lower respiratory tract. In present study, it was predicted that aspiration of oropharyngeal secretions prior to each position change will reduce the accumulation of oral secretion in the endotracheal tube cuff and reduce aspiration of contaminated secretion and reduce the risk of developing VAP. This randomized controlled experimental study was planned to confirm the validity of this assumption.

\section{Materials and methods}

This study was a randomized controlled experimental study designed to investigate the effect of oropharyngeal aspiration on decreasing the incidence of VAP in patients receiving mechanical ventilation. The population of the study consisted of patients hospitalized between July 2015 and April 2019 in anesthesiology and reanimation ICU. Forty patients who met the inclusion criteria were included in the study sample (Table 1).
Table 1 Research groups

\begin{tabular}{lccllr}
\hline Age group & \multicolumn{2}{l}{ Experimental group } & & \multicolumn{2}{l}{ Control group } \\
\cline { 2 - 3 } \cline { 6 - 7 } \cline { 5 - 6 } & Female & Male & & Female & Male \\
\hline 18-64 years & 5 & 5 & & 5 & 5 \\
65 years and older & 5 & 5 & & 5 & 5 \\
Total & 10 & 10 & & 10 & 10 \\
\hline
\end{tabular}

\section{Inclusion criteria}

- Over 18 years of age

- Supported mechanical ventilation by endotracheal tube

- $\geq 24 \mathrm{~h}$ remaining connected to mechanical ventilator

- Position could be changed every $4 \mathrm{~h}$ in a day

- Patients whose relatives approved to participate in the study

\section{Exclusion criteria}

- Pneumonia developed prior to mechanical ventilation support or within the first $48 \mathrm{~h}$ following mechanical ventilation support.

- Positive sputum culture was taken before mechanical ventilation support or within the first $48 \mathrm{~h}$ following mechanical ventilation support.

- Patients with diabetes mellitus.

- Patients with contraindications for routine change of position.

Relatives of patients who met the inclusion criteria were informed about the study and the "Patient Identification Form" was completed after obtaining informed consent.

Application of the research The patients who met the study criteria were assigned to the research groups by block randomization method according to age and gender (Table 1). The patients were randomly assigned to the experimental and control groups according to their bed numbers. Small pieces of paper with the bed numbers of the patients meeting the appropriate criteria were placed in a non-transparent bag. A healthcare worker who was not involved in the study was asked to select a piece of paper from the bag. The patient lying in the selected bed number was accepted as the first patient included in the study. The patients were assigned to groups by flipping a coin. If it was heads, the patient is assigned to the experimental group. If it was tails, the patient is assigned to the control group. After the first patient was assigned, the other bed number drawn from the bag was placed to another group. This process was repeated. To prevent possible confusion, a marker with the statement "that will be aspirated before the 
position is changed" was placed on the nurse observation form of the experimental groups.

Experimental group Patients in the experimental group underwent oropharyngeal aspiration prior to each position change in addition to routine nursing care (endotracheal aspiration and oropharyngeal aspiration as needed; oral care; routine (change of patient position was done every $4 \mathrm{~h}$ in a day) and non-routine position changes). Patients in this group underwent oropharyngeal aspiration at least 6 times in $24 \mathrm{~h}$ with a pressure of $100-120 \mathrm{mmHg}$ for $10 \mathrm{~s}$ prior to routine and non-routine position changes. The patient's position after the oropharyngeal aspiration was changed.

Control group The patients in the control group received routine nursing care in the ICU (endotracheal aspiration and oropharyngeal aspiration as needed; oral care; routine (change of patient position was done every $4 \mathrm{~h}$ in a day) and non-routine position changes).

All patients included in the study were followed for the development of VAP pneumonia. Participation of the patients in the experimental and control groups was continued until any one or more of the following criteria were met:

- Development of VAP

- Termination of the patient's mechanical ventilation support

- Transfer of the patient to another unit

- Discharge of the patient

- Development of exitus

Clinical Pulmonary Infection Score (CPIS) was used to diagnosis of VAP, and VAP was diagnosed in the patients whose CPIS was above 6 in the evaluation. Deep tracheal aspiration specimens were cultured for VAP agent/s. Antibiotic susceptibility of microorganisms grown in positive cultures was investigated.

\section{Data analysis}

In the analysis of the data, SPSS 15.0 statistical package program was used; descriptive statistics were shown with number and percentage, and measurement data with mean and standard deviation values. Student's $t$ test or Mann-Whitney $U$ test were used to compare independent variables between the groups. The chisquare $\left(\chi^{2}\right)$ test was used to compare the variables with two groups. Significance level was accepted as $p<0.05$.

\section{Results}

The mean age of the 40 patients was $62.87 \pm 17.33$ (min 22; $\max 91$ ) years. The mean and median length of stay in the ICU were $27.28 \pm 30.69$ and 18.00 (min 4 days; max 168 days) days respectively. A total of $32.5 \%$ of patients were hospitalized due to cerebrovascular event including pituitary tumor, brain malignant neoplasm, meningioma intracranial hemorrhage, infarction, and other cerebral vascular diseases (Table 2). The mean and median of mechanical ventilation support were $26.72 \pm 30.65$ and 18.00 (min 4 days; $\max$ 168 days) days respectively. A total of $27.5 \%$ of patients had undergone surgery. Chronic obstructive pulmonary disease (COPD) was present in $17.5 \%$ of patients. A total of $22.5 \%$ of patients received aerosol therapy. A total of $97.5 \%$ of patients had nasogastric tube. Forty-five percent of patients were fed with enteral nutrition via percutaneous endoscopic gastrostomy or nasogastric tube. Ten percent of patients were applied total parenteral nutrition. Antacid was administered to $77.5 \%$ of patients. The mean blood albumin level of patients was $3.17 \pm 0.57(\min 2.17 ; \max 4.80) \mathrm{g} / \mathrm{dL}$. VAP was developed in $30 \%$ of patients. The mean duration of VAP development was $7.50 \pm 5.07$ days of mechanical ventilation (min 3 days; $\max 18$ days). Multidrug resistant (MDR) A. baumannii and MDR $P$. aeruginosa were detected in $33.4 \%$ and $16.8 \%$ of the cultures made from deep tracheal aspiration samples (data not shown in table). As shown in Table 3, all isolated bacteria were multidrug resistant (Table 4).

A total of $8.3 \%$ of the experimental group patients who underwent oropharyngeal aspiration prior to change of position developed VAP; $91.7 \%$ of the control group patients without oropharyngeal aspiration developed VAP. VAP development was significantly different with respect to oropharyngeal aspiration before the change of position $\left(\chi^{2}=11.905\right.$; $p=0.001$ ) (Table 3 ). The mean age of the patients who developed VAP was $66.2 \pm 17.71(\min 22$; $\max 89)$, and the development of VAP did not show significant difference according to the mean of age $(t=0.843 ; p=0.405)$ (data not shown in table). A total of $66.7 \%$ of the patients who developed VAP were 65 years and older, and the difference of VAP development according to the age groups was not significant $\left(\chi^{2}=\right.$

Table 2 Reasons for hospitalization of patients in the intensive care unit

\begin{tabular}{lrc}
\hline Diagnosis & $n$ & $\%$ \\
\hline Liver transplantation & 1 & 2.5 \\
Suicide & 1 & 2.5 \\
Rheumatoid arthritis, muscular dystrophy & 2 & 5 \\
Respiratory failure & 7 & 15 \\
Heart failure, hypertension, diabetes mellitus & 8 & 20 \\
Cerebrovascular event & 12 & 32.5 \\
Malignancy * & 9 & 22.5 \\
Total & 128 & 100 \\
\hline
\end{tabular}

*Malignant neoplasm of the stomach, breast, colon, liver, lung, bladder, and biliary tract 
Table 3 Variation of VAP development according to patient variables

\begin{tabular}{|c|c|c|c|c|c|}
\hline \multirow[t]{3}{*}{ Variables } & & \multicolumn{4}{|c|}{ VAP development status } \\
\hline & & \multicolumn{2}{|c|}{ Yes } & \multicolumn{2}{|l|}{ No } \\
\hline & & $n$ & $\%$ & $n$ & $\%$ \\
\hline \multirow[t]{3}{*}{ Application oropharyngeal aspiration } & Yes & 1 & 8.3 & 19 & 67.9 \\
\hline & No & 11 & 91.7 & 9 & 32.1 \\
\hline & Pearson's chi-square $\left(\chi^{2}=11.905 ; p=0.001\right)$ & & & & \\
\hline \multirow[t]{3}{*}{ Age range } & $18-64$ years & 4 & 33.3 & 16 & 57.1 \\
\hline & 65 years and older & 8 & 66.7 & 12 & 42.9 \\
\hline & Pearson's chi-square $\left(\chi^{2}=1.905 ; p=0.168\right)$ & & & & \\
\hline \multirow[t]{3}{*}{ Gender } & Male & 8 & 66.7 & 12 & 42.9 \\
\hline & Female & 4 & 33.3 & 16 & 57.1 \\
\hline & Pearson's chi-square $\left(\chi^{2}=1.905 ; p=0.168\right)$ & & & & \\
\hline \multirow[t]{3}{*}{ COPD } & Yes & 2 & 16.7 & 5 & 17.9 \\
\hline & No & 10 & 83.3 & 23 & 82.1 \\
\hline & Fisher's exact test $\left(\chi^{2}=0.008 ; p=0.927\right)$ & & & & \\
\hline \multirow[t]{3}{*}{ Aerosol of treatment } & Yes & 3 & 25.0 & 6 & 21.4 \\
\hline & No & 9 & 75.0 & 22 & 78.6 \\
\hline & Fisher's exact test $\left(\chi^{2}=0.061 ; p=0.806\right)$ & & & & \\
\hline \multirow[t]{3}{*}{ Antibiotic treatment } & Yes & 12 & 34.3 & 23 & 87.5 \\
\hline & No & 0 & 0.0 & 5 & 12.5 \\
\hline & Fisher's exact test $\left(\chi^{2}=3.865 ; p=0.049\right)$ & & & & \\
\hline \multirow[t]{3}{*}{ Status of using antacid } & Yes & 10 & 83.3 & 21 & 77.5 \\
\hline & No & 2 & 16.7 & 7 & 22.5 \\
\hline & Fisher's exact test $\left(\chi^{2}=0.349 ; p=0.555\right)$ & & & & \\
\hline \multirow[t]{4}{*}{ Type of nutrition } & Absence & 6 & 50.0 & 12 & 42.9 \\
\hline & Parenteral & 3 & 25.0 & 15 & 53.6 \\
\hline & Enteral* & 3 & 25.0 & 1 & 3.6 \\
\hline & Fisher's exact test $\left(\chi^{2}=5.015 ; p=0.080\right)$ & & & & \\
\hline \multirow[t]{5}{*}{ Patient prognosis } & Transfer to another service & 1 & 8.3 & 10 & 35.7 \\
\hline & Termination of MV support** & 1 & 8.3 & 12 & 42.9 \\
\hline & Discharged & 1 & 8.3 & 0 & 0.0 \\
\hline & Exitus & 9 & 75.1 & 6 & 21.4 \\
\hline & Fisher's exact test $\left(\chi^{2}=13.112 ; p=0.002\right)$ & & & & \\
\hline
\end{tabular}

*Percutaneous endoscopic gastrostomy or nasogastric tube

**Mechanical ventilation

$1.905 ; p=0.168)$. A total of $66.7 \%$ of the patients who developed VAP were male. The development of VAP did not show significant difference according to gender $\left(\chi^{2}=1.905 ; p=\right.$ 0.168) (Table 3).

Twenty-five percent of the patients who developed VAP underwent surgery, and the development of VAP was not significantly different with respect to the surgical operation $\left(\chi^{2}=0.054 ; p=0.817\right)$ (data not shown in table). A total of $28.6 \%$ of the patients with COPD developed VAP and the development of VAP did not show significant difference according to the presence of COPD $\left(\chi^{2}=0.008 ; p=0.92\right)$. Twenty-five percent of patients with VAP have taken aerosol therapy. The development of VAP was not significantly different with respect to using of aerosol therapy $\left(\chi^{2}=0.061\right.$; $p=0.806$ ). All patients developing VAP were using antibiotics before VAP diagnosis. Increased use of antibiotic for prophylactic led to an increase in VAP development $\left(\chi^{2}=\right.$ $3.865 ; p=0.049)$. Antacid treatment was applied to $83.3 \%$ of patients with VAP. The development of VAP did not differ significantly according to antacid treatment status $\left(\chi^{2}=0.349\right.$; $p=0.555$ ) (Table 3).

The mean albumin level of patients with VAP was $2.96 \pm$ $0.48 \mathrm{~g} / \mathrm{dL}$. The mean serum albumin without VAP was $3.25 \pm$ $0.60 \mathrm{~g} / \mathrm{dL}$. The development of VAP did not change 


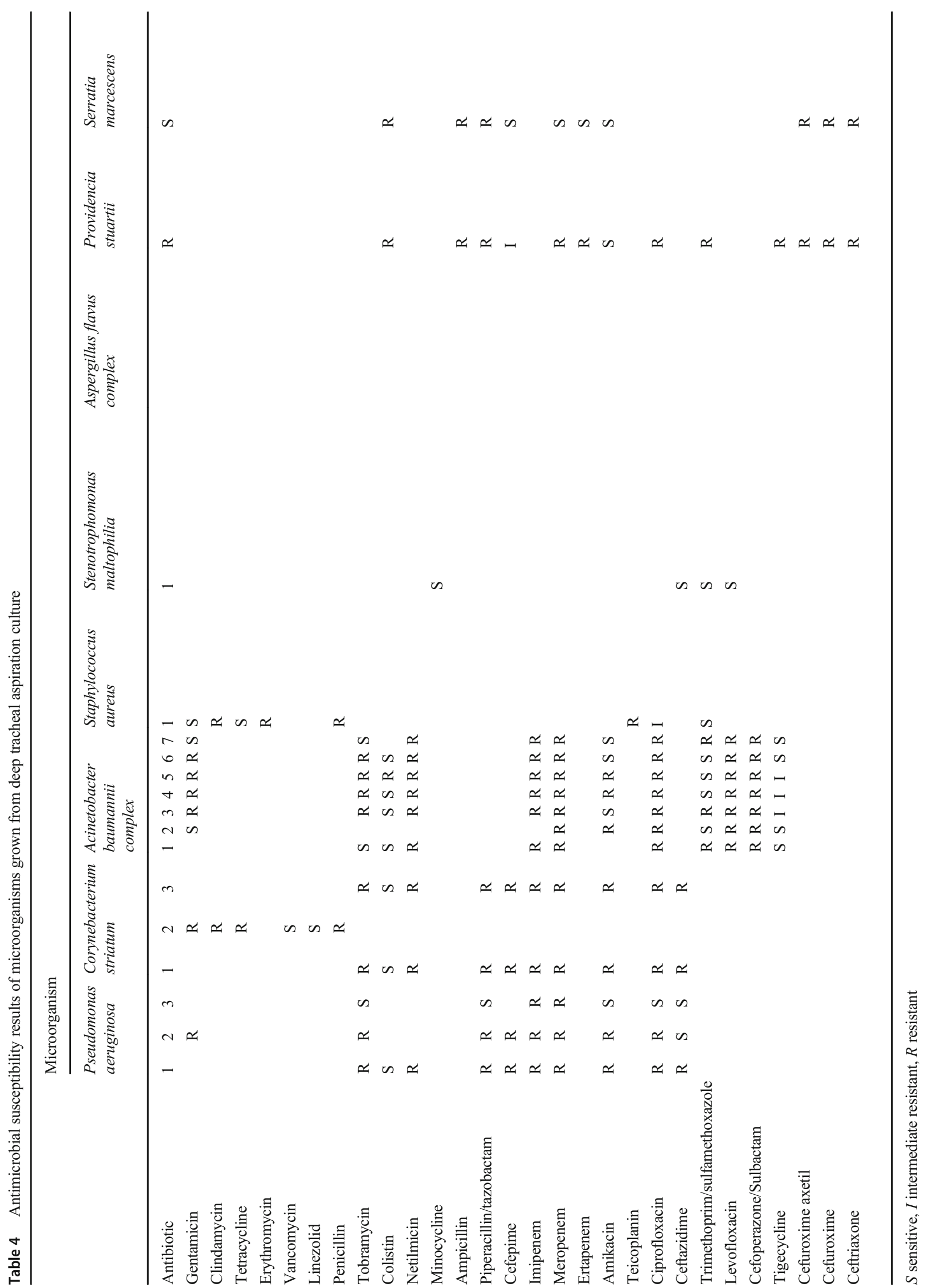


significantly according to blood albumin level $(t=-1.499$; $p=0.142$ ) (data not shown in table). Twenty-five percent of the patients who developed VAP were fed enterally; $25 \%$ were fed parenterally. The development of VAP was not significant difference with respect to patient nutrition $\left(\chi^{2}=\right.$ $5.015 ; p=0.080$ ) (Table 3 ). All patients with VAP had nasogastric tube.

A total of $75.1 \%$ of patients who developed VAP died; $24.9 \%$ were discharged, terminated of mechanical ventilation, and transferred to another service. There was a statistically significant difference between VAP development and patient prognosis, and VAP development increased the death rate significantly $\left(\chi^{2}=13.112 ; p=0.002\right)($ Table 3$)$

\section{Discussions}

The VAP is a common complication that increases morbidity and mortality in patients receiving mechanical ventilation support [16]. The incidence of VAP by INICC was $13.6 / 1000$ ventilator days. Although the mortality rate of VAP is higher in critically ill patients, it is reported to range from 24 to $76 \%$ $[4,16]$. VAP rate varies at regional level depending on the content and use of VAP prevention bundles to prevent the development of VAP in clinics. Hu and Zhou [17] found that VAP has developed in $40.60 \%$ of 234 patients. Uslu et al. [18] determined the rate of VAP as $23.3 / 1000$ ventilation days. Bilici et al. [6] calculated the incidence of VAP as 31.6 attacks/1000 ventilator days. In the current study, the rate of VAP was calculated to be $11.23 / 1000$ patient days. In this present study, the rate of VAP was lower than that of global statistical rates. We believed that the reason of these results may be due to the application of oropharyngeal aspiration to experimental group patients. VAP rates in the experimental and control groups (16.82/1000 mechanical ventilator days, $2.41 / 1000$ mechanical ventilator days, respectively) confirmed this view.

In this current study, the mean duration of VAP development was $7.50 \pm 5.07$ days of mechanical ventilation. In the literature, P. aeruginosa, Acinetobacter spp., Enterobacter spp., and $S$. aureus (methicillin resistant) were common among VAP agents developing after the fourth day of mechanical ventilation support [6-9]. In this context, in our study, based on the time of VAP development, we obtained results consistent with the literature in VAP cases that can be defined as late term VAP. MDR A. baumannii and MDR $P$. aeruginosa were among the most isolated bacteria in the development of VAP. This result was not surprising considering the epidemiological studies in our country. In epidemiological studies carried out in Turkey, A. baumannii was the most frequent cause of VAP and followed by $P$. aeruginosa. When the resistance profiles of the isolated bacteria were examined in the current study, the increase rates of carbapenem, quinolone, aminoglycoside, and colistin resistance were remarkable when compared with the previous studies [19-21]. This may be explained by the prevalence of uncontrolled antibiotic using.

The basic mechanism in the development of VAP can be explained by macroaspiration and microaspiration of oropharynx secretions due to functional impairment in the respiratory system. Continuous or intermittent oropharyngeal aspiration, closed system aspiration against open aspiration system, extensive oral care, and oropharyngeal aspiration prior to patient positioning were reported to prevent the development of oropharyngeal microaspiration $[7,16,19]$. In this currently study, only $8.3 \%$ of patients who underwent oropharyngeal aspiration prior to position change developed VAP; $91.7 \%$ of the patients who did not undergo oropharyngeal aspiration developed VAP, and oropharyngeal aspiration before the change of position significantly reduced the development of VAP $(p<0.05)$. In a clinical experimental study conducted by Chao et al. (2009), oropharyngeal aspiration before the change of patient position decreased VAP by 0.32 times, increased survival rate by 1.5 times, and shortened hospital stay. A similar result was found by Tsai, Lin, and Chang, [22]. There were also studies reporting that oropharyngeal aspiration in the comprehensive oral care reduces the incidence of VAP $[1,4,10,13-15]$. However, in a study in which oral secretion volumes were measured in intubated patients, some patients needed oropharyngeal aspiration every $2 \mathrm{~h}$ or more, and some patients needed at least $4 \mathrm{~h} \mathrm{[13].}$

According to the literature reports, risk factors for VAP include advanced age, neurosurgery and/or neurological trauma, thoraco-abdominal interventions, severe burns, long-term smoking, low serum albumin concentration, decreasing in consciousness, using of paralytic agents or sedation enhancing drugs, presence of nasogastric tube, aspiration of gastric contents, dysphagia, upper respiratory tract colonization, sinusitis, endotracheal intubation, prolonged mechanical ventilation, replacement of endotracheal tube frequently (re-intubation), contamination of humidifier, using of heated humidification system instead of humidifier filters, lack of oral care, body position, using of antacid or $\mathrm{H}_{2}$ receptor blockers, the presence of chronic diseases such as acute respiratory distress syndrome, chronic obstructive pulmonary disease, and diabetes mellitus, and the presence of more than three organ dysfunction were listed among the risk factors for VAP $[4,7-9,16]$.

In our study, the effect of these risk factors on the development of VAP was found to be higher in patients 65 years or older, although there was no significant difference $(p>0.05)$. Although male patients had a higher rate of VAP development, the development of VAP did not change significantly with respect to gender. Both expected results were thought to be related to gender and age randomization we used in the study design.

Although it was mentioned that taking aerosol therapy may be an effective factor in the development of VAP because of 
its potential to increase the risk of external contamination [4, 21 ], both in the current study and in the study of Chao et al. [7], it was concluded that aerosol treatment did not have a decisive effect on the development of VAP.

Although the presence of COPD has been reported to be one of the predictors of VAP $[18,22]$, the presence of COPD in the patient had no significant effect on the development of VAP $(p>0.05)$. There was no significant difference the rate of COPD between in the experimental and control groups (Fisher's exact test $\left[\chi^{2}=0.174 ; p=0.500\right]$ ). However, 2 of 4 COPD patients in the control group developed VAP. VAP did not develop in any of the patients with COPD in the experimental group. In our study, it was concluded that COPD was not a predisposing factor and may be due to intervention in the experimental group. This may also be related to the low incidence of COPD in our study group.

The use of antacids or $\mathrm{H}_{2}$ receptors to prevent stress ulcers is common in patients who are usually mechanically ventilated. It was reported that gastric preservatives alkalize the gastric fluid and increase bacterial colonization and therefore may be an effective factor in the development of VAP [4, 7, 23]. Although the rate of VAP development was higher in patients using antacids compared with those not using antacids, as in the study of Uslu et al. [18], we found that antacid use did not have a significant effect on the development of VAP $(p>0.05)$. It was thought that the absence of a significant difference, homogeneous distribution of antacid use in the experimental and control groups (Fisher's exact test $\left[\chi^{2}=\right.$ $1.310 ; p=0.451]$ ), and application from the experimental group could be the cause.

Although enteral nutrition was considered as a predictor factor in the development of VAP [6, 7, 18, 24], Chen et al. [25] reported that intermittent feeding or feeding with small volumes and administration of enteral feeding according to residual gastric content may prevent aspiration-induced VAP. We found that 3 of the 4 patients who underwent enteral feeding developed VAP. Contrary to other studies $[6,7,18,24]$, the development of VAP did not change significantly according to the nutritional status of the patients $(p>0.05)$.

Although it has been reported that low serum albumin levels may play a significant role in the development of VAP [4, 17], in our study, as in some studies [6, 7], serum albumin level did not have a significant effect on the development of VAP $(p>0.05)$. The majority of the patients with VAP (91.7\%) in the current study were control patients. As a matter of fact, the quality of the distribution of albumin levels of the control group patients was important and the blood albumin levels of the control group patients were homogeneously distributed (Fisher's exact test $\left[\chi^{2}=0.420 ; p=\right.$ $0.967])$. The reason for the lack of predisposing albumin level in VAP formation was thought to be due to this homogeneous distribution in the control group.
VAP developed in $55 \%$ of the patients treated with antibiotics. Contrary to Chao et al. [7], antibiotic use significantly increased the development of VAP $(p<0.05)$. Similar to the results obtained in our study, there were studies that found antibiotic use among the predisposing factors in the development of VAP [18, 26, 27]. Although prophylactic antibiotic use has been reported to reduce the incidence of VAP, longterm prophylactic antibiotic use will also alter drug resistance patterns in pathogens [28]. These antibiotics used for prophylaxis will not be effective in protecting against these resistant pathogens but will also make the treatment of VAP patient more difficult.

\section{Limitation}

In order to exclude external factors in the design of the study, it was preferred to carry out a uniform intensive care unit and study within a certain period of time. As such, this limited the number of patients included in the study.

\section{Conclusions}

The incidence of VAP was significantly lower in the experimental group compared with the control group. In addition, it was found that VAP development did not differ significantly according to factors such as patient age, presence of COPD, enteral nutrition, use of antacid, and albumin level. On the other hand, parallel to the increase in antibiotic use, VAP also increased. The increase in VAP development was determined to increase parallel mortality rates. In this current study, it was concluded that the removal of oropharyngeal secretions by oropharyngeal aspiration can prevent the development of VAP just before the patient is positioned. As a result of "oropharyngeal aspiration before the change of patient position significantly reduced the development of VAP," it shows that this application should be included in VAP prevention bundles.

\section{Compliance with ethical standards}

Conflict of interest The authors declare that they have no conflict of interests.

Ethical approval In addition, permission was obtained from the institution. Ethical approval was obtained from the Ethical Committee (number B.30.2.EGE.0.20.05.00/ OY/868/344; decision number 15-5.2/7). Research ClinicalTrials.gov. registered and received number (NCT04107363).

Informed consent Oral and written approvals were obtained from the patient relatives who agreed to take part in the study, and their identities were kept confidential. 


\section{References}

1. Hutchins K, Karras G, Erwin J, Sullivan KL (2009) Ventilatorassociated pneumonia and oral care: a successful quality improvement project. Am J Infect Control 37(7):590-597. https://doi.org/ 10.1016/j.ajic.2008.12.007

2. Tüfek A (2013) Evaluation of hospital infections developing in intensive care unit during a decade and review of literature. Dicle Med J / Dicle Tip Derg 39(4):492-498

3. Akıncı C, Çakar N, Ayyıldız A, Atalan HK, Ayyıldız A (2010) Yoğun Bakım Hemșirelerinin Ventilatör İlişskili Pnömoni ile İlgili Bilgilerinin Değerlendirilmesi. 38(1):45-51

4. Charles MVP, Kali A, Easow JM, Joseph NM, Ravishankar M, Srinivasan S et al (2014) Ventilator-associated pneumonia. Australas Med J 7(8):334-344

5. Van Nieuwenhoven CA, Vandenbroucke-Grauls C, Van Tiel FH, Joore HCA, RJM SVS, Van Der Tweel I et al (2006) Feasibility and effects of the semirecumbent position to prevent ventilatorassociated pneumonia: a randomized study. Crit Care Med 34(2): 396-402

6. Bilici A, Kas M, Yap K, Menteș O, Sünnetçioğlu A (2012) Ventilatör İlişkili Pnömoni S1klığı Risk Faktörleri ve Etkenleri. Van Tip Derg 19(4):170-176

7. Chao Y-FC, Chen Y-Y, Wang K-WK, Lee R-P, Tsai H (2009) Removal of oral secretion prior to position change can reduce the incidence of ventilator-associated pneumonia for adult ICU patients: a clinical controlled trial study. J Clin Nurs 18(1):22-28 Available from: http://www.ncbi.nlm.nih.gov/pubmed/19120729

8. Arumugam S, Mudali I, Strandvik G, El-Menyar A, Al-Hassani A, Al-Thani H (2018) Effects of ramipril on ventricular arrhythmia after myocardial infarction in PubMed Commons. World J Emerg Med 8(1):1-2

9. Chouhdari A, Shokouhi S, Bashar FR, Vahedian Azimi A, Shojaei SP, Fathi $M$ et al (2018) Is a low incidence rate of ventilation associated pneumonia associated with lower mortality? A descriptive longitudinal study in Iran. Tanaffos 17(2):110-116 Available from: http:// www.ncbi.nlm.nih.gov/pubmed/30627182\%0Ahttp:// www.pubmedcentral.nih.gov/articlerender.fcgi?artid=PMC6320555

10. Eom JS, Lee MS, Chun HK, Choi HJ, Jung SY, Kim YS et al (2014) The impact of a ventilator bundle on preventing ventilatorassociated pneumonia: a multicenter study. Am J Infect Control 42(1):34-37. https://doi.org/10.1016/j.ajic.2013.06.023

11. Klompas M, Branson R, Eichenwald EC, Greene LR, Howell MD, Lee $\mathrm{G}$ et al (2014) Strategies to prevent ventilator-associated pneumonia in acute care hospitals: 2014 update. Infect Control Hosp Epidemiol 35(Suppl 2(May 2019)):S133-S154 Available from: http:/www.ncbi.nlm.nih.gov/pubmed/25376073

12. Heyland D, Cook D, Dodek P (2002) Prevention of ventilatorassociated pneumonia: current practice in Canadian intensive care units. J Crit Care 17(3):161-167

13. Sole ML, Penoyer DA, Bennett M, Bertrand J, Talbert S (2011) Oropharyngeal secretion volume in intubated patients: the importance of oral suctioning. Am J Crit Care 20(6):141-146

14. Powers J, Brower A, Tolliver S (2007) Impact of oral hygiene on prevention of ventilator-associated pneumonia in neuroscience patients. J Nurs Care Qual 22(4):316-321

15. Garcia R, Jendresky L, Colbert L, Bailey A, Zaman M, Majumder M (2009) Reducing ventilator-associated pneumonia through advanced oral-dental care: a 48-month study. Am J Crit Care 18(6): $523-532$
16. Miller F. Intensive tutorial 382 Ventilator-associated pneumonia. Wfsa [Internet]. 2018;(June):1-6. Available from: https://www. wfsahq.org/components/com_virtual library/media/ 5e63c8f14e8a46c186bb0f73eafa2950-atow-382-00-01.pdf

17. Hu Z, Zhou S (2018) Risk factors and etiological analysis of ventilator-associated pneumonia: three year's cases analysis of intensive care unit in county hospital. Zhonghua Wei Zhong Bing Ji Jiu Yi Xue 30(10):933-938

18. Uslu M, Ozturk DB, Kuscu F, Aslan V, Gurbuz Y, Tutuncu EE et al (2011) Risk factors for ventilator-associated pneumonia developing in patients admitted to intensive care unit. Klimik Dergisi/Klimik J 23(3):83-88

19. But A, Yetkin MA, Kanyilmaz D, Aslaner H, Baștuğ A, Aypak A et al (2017) Analysis of epidemiology and risk factors for mortality in ventilator-associated pneumonia attacks in intensive care unit patients. Turkish J Med Sci 47(3):812-816

20. Çukurova Z, Durdu B, Hergünsel O, Eren G, Tekdöş Y, Durdu Y (2012) Invasive device-related nosocomial infection surveillance in intensive care unit. Turkiye Klin J Med Sci 32(2):438-443

21. Dizbay M, Baş S, Gürsoy A, Şimşek H, Maral I, Aktaş F (2009) Invasive device-related infection surveillance in intensive care units of Gazi University Hospital in 2006-2007. Turk Klin Tip Bilim 29(1):140-145

22. Tsai H, Lin F, Chang S (2008) Intermittent suction of oral secretions before each positional change may reduce ventilatorassociated pneumonia: a pilot study. Am J Med Sci 336(5):397-401

23. Craven D, Lichtenberg D, Goularte T, Make B, McCabe W (1984) Contaminated medication nebulizers in mechanical ventilator circuits. Source of bacterial aerosols. Am J Med 77(5):834-838

24. Thompson R (1996) Incidence of ventilator-associated pneumonia (VAP) with 14-day circuit change in a subacute environment. Respir Care 41(7):601-606

25. Chen YC (2009) Critical analysis of the factors associated with enteral feeding in preventing VAP: a systematic review. J Chinese Med Assoc [Internet] 72(4):171-178. https://doi.org/10.1016/ S1726-4901(09)70049-8

26. Ehman EC, Johnson GB, Villanueva-meyer JE, Cha S, Leynes AP, Eric $P$ et al (2017) Enteral nutrition and acid-suppressive therapy in the pediatric intensive care unit: impact on the risk of ventilatorassociated pneumonia. Pediatr Crit Care Med 46(5):1247-1262

27. Djazmati W, Memish Z, Oni G, Cunningham G, Beyene Y, Al SA (2001) The influence of enteral feeding on ventilator associated pneumonia (VAP) in trauma mechanically ventilated patients in ICU. Crit Care 5(1):P152

28. Wu D, Wu C, Zhang S, Zhong Y (2019) Risk factors of ventilatorassociated pneumonia in critically III patients. Front Pharmacol 10(MAY):1-7

29. Chang L, Dong Y, Zhou P (2017) Investigation on risk factors of ventilator-associated pneumonia in acute cerebral hemorrhage patients in intensive care unit. Can Respir J 2017:1-4

30. Mangram AJ, Sohn J, Zhou N, Hollingworth AK, Ali-Osman FR, Sucher JF et al (2015) Trauma-associated pneumonia: time to redefine ventilator-associated pneumonia in trauma patients. Am J Surg 210(6):1056-1062. https://doi.org/10.1016/j.amjsurg.2015.06.029

31. Zarzaur BL, Bell TM, Croce MA, Fabian TC (2013) Geographic variation in susceptibility to ventilator-associated pneumonia after traumatic injury. J Trauma Acute Care Surg 75(2):234-240

Publisher's note Springer Nature remains neutral with regard to jurisdictional claims in published maps and institutional affiliations. 